\title{
THE
}

1995

\section{US Fish and Wildlife Service 1979 wetland classification: A review}

Lewis M. Cowardin

Francis C. Golet

University of Rhode Island, fgolet@uri.edu

Follow this and additional works at: https://digitalcommons.uri.edu/nrs_facpubs

Terms of Use

All rights reserved under copyright.

\section{Citation/Publisher Attribution}

Cowardin, L.M. \& Golet, F.C. Vegetatio (1995) 118: 139. https://doi.org/10.1007/BF00045196

Available at: http://dx.doi.org/10.1007/BF00045196

This Article is brought to you for free and open access by the Natural Resources Science at DigitalCommons@URI. It has been accepted for inclusion in Natural Resources Science Faculty Publications by an authorized administrator of DigitalCommons@URI. For more information, please contact digitalcommons-group@uri.edu. 


\title{
US Fish and Wildlife Service 1979 wetland classification: A review*
}

\author{
Lewis M. Cowardin ${ }^{1}$ \& Francis C. Golet ${ }^{2}$ \\ ${ }^{1}$ US Fish and Wildlife Service, Northern Prairie Wildlife Research Center, Jamestown, ND 58401, USA; \\ ${ }^{2}$ Department of Natural Resources Science, University of Rhode Island, Kingston, RI 02881, USA
}

Key words: Classification, Definition, United States, Wetland

\begin{abstract}
In 1979 the US Fish and Wildlife Service published and adopted a classification of wetlands and deepwater habitats of the United States. The system was designed for use in a national inventory of wetlands. It was intended to be ecologically based, to furnish the mapping units needed for the inventory, and to provide national consistency in terminology and definition. We review the performance of the classification after 13 years of use. The definition of wetland is based on national lists of hydric soils and plants that occur in wetlands. Our experience suggests that wetland classifications must facilitate mapping and inventory because these data gathering functions are essential to management and preservation of the wetland resource, but the definitions and taxa must have ecological basis. The most serious problem faced in construction of the classification was lack of data for many of the diverse wetland types. Review of the performance of the classification suggests that, for the most part, it was successful in accomplishing its objectives, but that problem areas should be corrected and modification could strengthen its utility. The classification, at least in concept, could be applied outside the United States. Experience gained in use of the classification can furnish guidance as to pitfalls to be avoided in the wetland classification process.
\end{abstract}

\section{Introduction}

\section{Development of US Classification}

The wetland classification in use today by the US Fish and Wildlife Service (USFWS) was developed between 1975 and 1979 (Cowardin et al. 1979). It originated from a need by the USFWS to inventory the wetland resources of the United States. The stated purposes of the classification were to: (1) describe ecological units that have certain homogeneous natural attributes; (2) arrange those units in a system that would aid decisions about resource management; (3) furnish units for inventory and mapping; and (4) provide uniformity in concepts and terminology throughout the United States. The history and development of the classification is closely related to the development of the National Wetland Inventory (NWI). This paper describes and evaluates the classification. The inventory is described by Wilen and Bates (this volume).

* The US Government's right to retain a non-exclusive, royalty free licence in and to any copyright is acknowledged.
The USFWS has a long history of involvement in wetland classification and inventory. Conservation and management of migratory waterfowl are a responsibility of the USFWS based on migratory bird treaties with Canada and Mexico. Thus, conservation of wetland habitats is one of the agency's primary objectives. The USFWS conducted the first quantitative national inventory of wetlands in the mid-1950s; the results were summarized in US Fish and Wildlife Service Circular 39 (Shaw \& Fredine 1956). That inventory was based on a classification, developed by Martin et al. (1953), which included 20 classes of wetlands. After close scrutiny, the authors found that the Martin et al. classification was inconsistently applied among regions. The reason was primarily lack of detail in definitions. By the mid-1970s, when the current inventory was being planned, there had been an explosion of public and professional interest in wetlands that transcended the habitat function for migratory birds. Numerous excellent regional classifications (e.g., Stewart \& Kantrud 1971, Golet \& Larson 1974; Jeglum et al. 
1974; Odum et al. 1974; Zoltai et al. 1975; Millar 1976) also had been developed since the Martin et al. classification.

In January of 1975, the USFWS convened a small number of interested individuals from various agencies and regions to formulate the skeleton of a new classification that could serve as the basis for a new national wetlands inventory. Three important points were agreed upon: (1) none of the existing classifications met the requirement for national uniformity, (2) regional classifications would not suffice because of the confusion resulting at regional boundaries, and (3) a new classification should be hierarchical in structure. Following that meeting, Cowardin and Carter (1975) prepared a tentative classification that was presented at a July 1975 national workshop, where 150 federal and state wetland management personnel were invited to comment on the proposed classification (Sather 1976). Input from that workshop resulted in major modifications of the Cowardin and Carter paper and led to the preparation of a revision, Interim Classification of Wetlands and Aquatic Habitats of the United States (Cowardin et al. 1976). The revised system was tested using both high- and low-altitude aerial photographs and field-checks at 21 sites scattered across the country. The NWI staff worked with the authors of the 1976 classification to resolve practical problems encountered during testing. At the same time, the authors tested the evolving classification at numerous locations throughout the United States. The final version was published in 1979 (Cowardin et al. 1979); it was reprinted in 1985 and 1992. The classification has been used by the NWI for 13 years. It has also been widely used by other federal and state regulatory and resource management agencies, as well as by wetland researchers.

\section{Objectives of paper}

This paper has four objectives: (1) to acquaint the reader with the structure of the USFWS classification system, (2) to explain the rationale for the approach to classification, (3) to review successes as well as problems encountered during its use, and (4) to evaluate the potential for use of the system on an international scale.

\section{Overview of the classification}

\section{Definition of wetland and deepwater habitat}

Under the USFWS classification (Cowardin et al. 1979:3), wetlands are defined as follows:

Wetlands are lands transitional between terrestrial and aquatic systems where the water table is usually at or near the surface or the land is covered by shallow water. For the purposes of this classification wetlands must have one or more of the following three attributes: (1) at least periodically, the land supports predominantly hydrophytes; (2) the substrate is predominantly undrained hydric soil; and (3) the substrate is nonsoil and is saturated with water or covered by shallow water at some time during the growing season of each year.

In support of this definition, the USFWS has prepared a list of plants known to occur in U.S. wetlands. The first draft, released in 1977, contained 4235 species; the latest version includes more than 7000 species (Reed 1988). Each of the species in this list is placed into one of four categories according to its frequency of occurrence in wetlands: Obligate Wetland, Facultative Wetland, Facultative, or Facultative Upland (see Table 1 for definitions).

Also to supplement the USFWS wetland definition, the US Soil Conservation Service has developed a definition of hydric soil, taxonomic and hydrologic criteria for identifying hydric soils, and a list of the hydric soils of the United States. The first draft, Hydric Soils of the United Sates, was published in 1982 (Soil Conservation Service 1982) and subsequent editions (Soil Conservation Service 1985, 1987, 1991) were released. In the latest edition (Soil Conservation Service 1991:1), hydric soil is defined as follows:

A hydric soil is a soil that is saturated, flooded, or ponded long enough during the growing season to develop anaerobic conditions in the upper part.

The aim of the NWI was to map not only those areas traditionally regarded as wetlands, but also those deeper waters which frequently are associated with wetlands. For that reason, Cowardin et al. (1979) made a clear distinction between wetlands and 'deepwater habitats'. The latter were defined as permanently flooded lands lying below the deepwater boundary of wetlands. In nontidal areas, the boundary between wetland and deepwater habitat was placed at a depth of $2 \mathrm{~m}$ below low water - the maximum depth to which rooted, emergent plants normally grow (Welch 1952; Zhadin 
Table 1. Wetland indicator categories for plants that occur in US wetlands (from Reed 1988).

\begin{tabular}{ll}
\hline Category & Definition \\
\hline Obligate wetland & $\begin{array}{l}\text { Under natural conditions, occurs almost always (estimated probability >99\%) in } \\
\text { wetlands. }\end{array}$ \\
Facultative wetland & $\begin{array}{l}\text { Usually occurs in wetlands (estimated probability 67-99\%), but occasionally } \\
\text { found in nonwetlands. }\end{array}$ \\
Facultative & $\begin{array}{l}\text { Equally likely to occur in wetlands or nonwetlands (estimated probability 34 } \\
66 \%) .\end{array}$ \\
Facultative upland & $\begin{array}{l}\text { Usually occurs in nonwetlands (estimated probability 67-99\%, but occasionally } \\
\text { found in wetlands (estimated probability 1\%-33\%) }\end{array}$ \\
\hline
\end{tabular}

\& Gerd 1963; Sculthorpe 1967). Marked, short-term fluctuations in the level of tidal waters called for different criteria for separating wetlands from deepwater habitats. In tidal areas the boundary was placed at the elevation of extreme low water; thus, sites that are permanently covered with tidal water are considered deepwater habitats, regardless of water depth.

\section{Hierarchical structure of the classification}

The classification structure consists of five levels, arranged in a hierarchical fashion. Proceeding from the highest to the lowest level, these are: Systems, Subsystems, Classes, Subclasses, and Dominance Types. Figure 1 illustrates the classification structure to the Class level, and Table 2 presents the distribution of Subclasses within the classification hierarchy.

The System is the uppermost level in the classification. It describes the overall complex of hydrological, geomorphological, physical, chemical, and biological features that certain groups of wetlands and deepwater habitats share. Five Systems are recognized: Marine, Estuarine, Riverine, Lacustrine, and Palustrine. Salinity, wave energy, basin morphology, water depth, and surface water area are some of the key features distinguishing Systems.

Systems are further divided into Subsystems, primarily on the basis of water depth, surface water permanence, or, in the case of the Riverine System, stream gradient and extent of tidal influence. Marine and Estuarine Systems each have two Subsystems, Subtidal and Intertidal; the Lacustrine System has two Subsystems, Limnetic and Littoral; and the Riverine System has four Subsystems, Tidal, Lower Perennial, Upper Perennial, and Intermittent. The Palustrine System is not divided into Subsystems.

The Class is the third level in the classification hierarchy. It may be thought of as the basic habitat type. The Class describes the general appearance of the habitat in terms of either the dominant life form of the vegetation, in the case of vegetated habitats, or the form and general composition of the substrate, along with water regime, in the case of nonvegetated habitats. The same Class may occur within two or more Systems or Subsystems (Fig. 1). There are six Classes of nonvegetated habitats: Rock Bottom, Unconsolidated Bottom, Rocky Shore, Unconsolidated Shore, Streambed, and Reef. Vegetated Classes include: Aquatic Bed, Emergent (herbaceous) Wetland, Scrub-Shrub Wetland, Forested Wetland, and Moss-Lichen Wetland.

Each of the 11 Classes contains two or more Subclasses (Table 2). Subclasses are distinguished by finer differences in either vegetative life form or substrate composition. For example, Forested Wetlands are divided into five Subclasses: Broad-leaved Deciduous, Needle-leaved Deciduous, Broad-leaved Evergreen, Needle-leaved Evergreen, and Dead. Unconsolidated Bottoms have four Subclasses: Cobble-Gravel, Sand, Mud, and Organic.

Dominance Type is the lowest level in the classification hierarchy. It describes the dominant plant or sedentary or sessile animal species within a particular Subclass at a specific site. When the Subclass is based on vegetative life form, the Dominance Type is the most abundant single species, or combination of species (in the case of codominance), in the vegetation layer used to name the Subclass. Thus, in a Broad-leaved Deciduous Forested Wetland, the Dominance Type would be the most abundant broad-leaved deciduous tree species (e.g., Acer rubrum). When the Subclass is based on substrate composition, the Dominance Type is the predominant plant or sedentary or sessile macroinvertebrate species on the site. Dominance Types are not listed in the classification; they are determined onsite by the user. 


\begin{tabular}{|c|c|c|c|c|c|c|c|c|c|c|c|}
\hline \multirow[b]{3}{*}{ Class/Subclass } & \multicolumn{11}{|c|}{ System and Subsystem } \\
\hline & \multicolumn{2}{|c|}{ Marine } & \multicolumn{2}{|c|}{ Estuarine } & \multicolumn{4}{|c|}{ Riverine } & \multicolumn{2}{|c|}{ Lacustrine } & \multirow{2}{*}{$\frac{\text { Palustrine }}{-}$} \\
\hline & ST & IT & ST & IT & TI & LP & UP & $\mathrm{IN}$ & $\mathrm{LM}$ & LT & \\
\hline \multicolumn{12}{|l|}{ Rock Bottom } \\
\hline Bedrock & $\mathrm{X}$ & & $\mathrm{X}$ & & $\mathrm{X}$ & & $\mathrm{X}$ & & $x$ & $\mathrm{x}$ & $\mathrm{X}$ \\
\hline Rubble & $\mathrm{X}$ & & $\mathrm{x}$ & & $x$ & & $\mathrm{X}$ & & $\mathrm{X}$ & $\mathrm{x}$ & $\mathrm{X}$ \\
\hline \multicolumn{12}{|l|}{ Unconsolidated Bottom } \\
\hline Cobble-Gravel & $\mathrm{X}$ & & $\mathrm{x}$ & & $x$ & $\mathrm{x}$ & $\mathrm{X}$ & & $\mathrm{X}$ & $\mathrm{X}$ & $\mathrm{x}$ \\
\hline Sand & $\mathrm{X}$ & & $\mathrm{X}$ & & $\mathrm{x}$ & $x$ & $\mathrm{x}$ & & $\mathrm{X}$ & $\mathrm{X}$ & $x$ \\
\hline Mud & $\mathrm{X}$ & & $\mathrm{X}$ & & $\mathrm{X}$ & $\mathrm{x}$ & $\mathrm{x}$ & & $\mathrm{x}$ & $\mathrm{X}$ & $\mathrm{x}$ \\
\hline Organic & & & $\mathrm{X}$ & & $\mathrm{X}$ & $\mathrm{x}$ & & & $\mathrm{x}$ & $\mathrm{X}$ & $x$ \\
\hline \multicolumn{12}{|l|}{ Aquatic Bed } \\
\hline Algal & $\mathrm{X}$ & $\mathrm{X}$ & $\mathrm{X}$ & $\mathrm{x}$ & $\mathrm{x}$ & $\mathrm{x}$ & $\mathrm{X}$ & & $\mathrm{X}$ & $x$ & $x$ \\
\hline Aquatic Moss & & & & & $\mathrm{X}$ & $\mathrm{X}$ & $\mathrm{X}$ & & $\mathrm{x}$ & $\mathrm{x}$ & $\mathrm{X}$ \\
\hline Rooted Vascular & $\mathrm{x}$ & $\mathrm{x}$ & $\mathrm{x}$ & $\mathrm{x}$ & $\mathrm{X}$ & $\mathrm{x}$ & $x$ & & $x$ & $\mathrm{X}$ & $\mathrm{X}$ \\
\hline Floating Vascular & & & $\mathrm{X}$ & $\mathrm{X}$ & $\mathrm{x}$ & $\mathrm{x}$ & $x$ & & $\mathrm{x}$ & $\mathrm{x}$ & $\mathrm{X}$ \\
\hline \multicolumn{12}{|l|}{ Reef } \\
\hline Coral & $\mathrm{X}$ & $\mathrm{X}$ & & & & & & & & & \\
\hline Mollusk & & & $\mathrm{x}$ & $\mathrm{X}$ & & & & & & & \\
\hline Worm & $\mathrm{X}$ & $\mathrm{X}$ & $\mathrm{X}$ & $\mathrm{X}$ & & & & & & & \\
\hline \multicolumn{12}{|l|}{ Streambed } \\
\hline Bedrock & & & & $\mathrm{X}$ & $\mathrm{X}$ & & & $\mathrm{X}$ & & & \\
\hline Rubble & & & & $\mathrm{x}$ & $\mathrm{X}$ & & & $\mathrm{X}$ & & & \\
\hline Cobble-Gravel & & & & $\mathrm{X}$ & $\mathrm{X}$ & & & $\mathrm{X}$ & & & \\
\hline Sand & & & & $\mathrm{X}$ & $\mathrm{X}$ & & & $\mathrm{X}$ & & & \\
\hline Mud & & & & $\mathrm{X}$ & $\mathrm{x}$ & & & $\mathrm{X}$ & & & \\
\hline Organic & & & & $\mathrm{X}$ & $\mathrm{X}$ & & & $\mathrm{X}$ & & & \\
\hline Vegetated & & & & & & & & $\ddot{x}$ & & & \\
\hline \multicolumn{12}{|l|}{ Rocky Shore } \\
\hline Bedrock & & $\mathrm{x}$ & & $\mathrm{X}$ & $\mathrm{x}$ & $\mathrm{x}$ & $\mathrm{x}$ & & & $\mathrm{X}$ & \\
\hline Rubble & & $\mathrm{x}$ & & $\mathrm{X}$ & $\mathrm{X}$ & $x$ & $\mathrm{X}$ & & & $\mathrm{X}$ & \\
\hline \multicolumn{12}{|l|}{ Unconsolidated Shore } \\
\hline Cobble-Gravel & & $\mathrm{x}$ & & $\mathrm{X}$ & $\mathrm{x}$ & $\mathrm{X}$ & $\mathrm{X}$ & & & $\mathrm{X}$ & $\mathrm{X}$ \\
\hline Sand & & $\mathrm{X}$ & & $\mathrm{X}$ & $\mathrm{X}$ & $\mathrm{X}$ & $\mathrm{X}$ & & & $\mathrm{x}$ & $\mathrm{X}$ \\
\hline Mud & & $\mathrm{x}$ & & $\mathrm{X}$ & $\mathrm{x}$ & $\mathrm{X}$ & $\mathrm{X}$ & & & $\mathrm{x}$ & $\mathrm{X}$ \\
\hline Organic & & $\mathrm{x}$ & & $x$ & $\mathrm{X}$ & $\mathrm{x}$ & $\mathrm{X}$ & & & $\mathrm{X}$ & $\mathrm{X}$ \\
\hline Vegetated & & & & & $\mathrm{X}$ & $x$ & $\ddot{x}$ & & & $\mathrm{x}$ & $\mathrm{x}$ \\
\hline \multicolumn{12}{|l|}{ Moss-Lichen Wetland } \\
\hline Moss & & & & & & & & & & & $\mathrm{x}$ \\
\hline Lichen & & & & & & , & & & & & $\mathrm{X}$ \\
\hline \multicolumn{12}{|l|}{ Emergent Wetland } \\
\hline Persistent & & & & $\mathrm{x}$ & & & & & & & $\mathrm{x}$ \\
\hline Nonpersistent & & & & $\ddot{x}$ & $\mathrm{x}$ & $\mathrm{X}$ & $\mathrm{X}$ & & & $x$ & $\mathrm{x}$ \\
\hline Scrub-Shrub Wetland & & & & & & & & & & & \\
\hline Broad-leaved Deciduous & & & & $x$ & & & & & & & $\mathrm{X}$ \\
\hline Needle-leaved Deciduous & & & & $\mathrm{X}$ & & & & & & & $\mathrm{X}$ \\
\hline Broad-leaved Evergreen & & & & $x$ & & & & & & & $\mathrm{X}$ \\
\hline Needle-leaved Evergreen & & & & $\mathrm{x}$ & & & & & & & $x$ \\
\hline Dead & & & & $\mathrm{X}$ & & & & & & & $\mathrm{x}$ \\
\hline Forested Wetiand & & & & & & & & & & & \\
\hline Broad-leaved Deciduous & & & & $x$ & & & & & & & $\mathrm{X}$ \\
\hline Needle-leaved Deciduous & & & & $\mathrm{X}$ & & & & & & & $\mathrm{X}$ \\
\hline Broad-leaved Evergreen & & & & $\mathrm{x}$ & & & & & & & $\mathrm{X}$ \\
\hline Needle-leaved Evergreen & & & & $\mathrm{x}$ & & & & & & & $\mathrm{X}$ \\
\hline Dead & & & & $x$ & & & & & & & $x$ \\
\hline
\end{tabular}

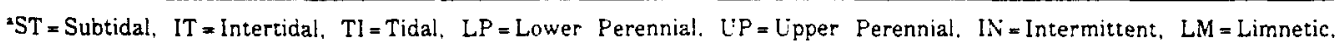
$\mathrm{LT}=$ Littoral .

Fig. 1. Classification hierarchy of wetlands and deepwater habitats, showing Systems, Subsystems, and Classes in the USFWS classification (from Cowardin et al. 1979: Fig. 1). The Palustrine System does not include deepwater habitats. 
Table 2. Distribution of Subclasses within the USFWS classification hierarchy (from Cowardin et al. 1979: Table 1).

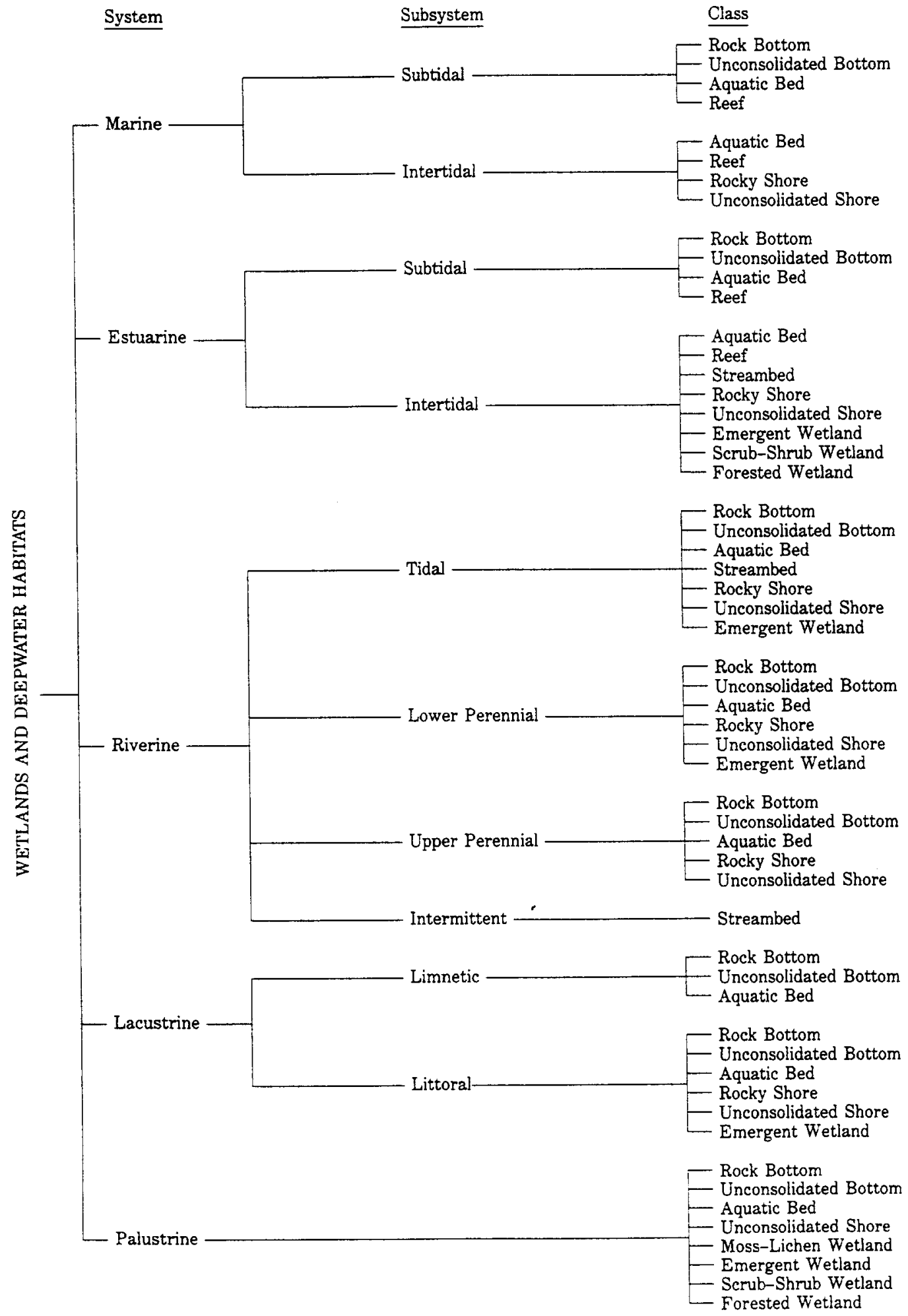




\section{Modifiers}

Besides vegetation and substrate composition, the classification addresses several other aspects of wetlands and deepwater habitats, namely water regime, water chemistry, soil type, and modification by humans or beavers (Castor canadensis). These features are treated as Modifiers that are applied once the habitat has been placed in the classification hierarchy.

Without long-term measurements of water levels at individual sites, it is impossible to accurately describe a site's hydrologic regime, but the authors of the classification believed that even broad categorization of hydrology can be useful. Water Regime Modifiers provide a gross description of a site's water regime, the frequency and duration of surface water inundation or soil saturation. Two major categories of water regimes are recognized, Tidal and Nontidal. Tidal Water Regime Modifiers describe the frequency and duration of flooding or exposure by ocean tides; four are recognized: subtidal, irregularly exposed, regularly flooded, and irregularly flooded. Nontidal Water Regime Modifiers describe hydrologic conditions at inland sites during the growing season; the eight Nontidal Modifiers are: permanently flooded, intermittently exposed, semipermanently flooded, seasonally flooded, saturated, temporarily flooded, intermittently flooded, and artificially flooded.

Water Chemistry Modifiers address two key variables, salinity (Cowardin et al. 1979: Table 2) and hydrogen-ion concentration or $\mathrm{pH}$ (Cowardin et al. 1979: Table 3). All habitats are classified according to salinity, and freshwater habitats ( $<0.5 \mathrm{ppt}$ salinity) are further classified by $\mathrm{pH}$. The suffix 'haline' is used for the Marine and Estuarine Systems, in which ocean salts predominate, while the suffix 'saline' is reserved for Riverine, Lacustrine, and Palustrine Systems; however, the same prefixes and hierarchy of salinity values apply to inland and coastal habitats.

Soil Modifiers, taken directly from Soil Taxonomy (Soil Survey Staff 1975), are used for those wetlands in which an unconsolidated substrate is capable of supporting emergent herbs, emergent mosses, lichens, shrubs, or trees. Deepwater habitats and wetlands that are too wet to support emergent vegetation are not considered to have soil. Wetland soils are broken into two major categories, mineral and organic.

Finally, a series of Special Modifiers was developed to indicate that certain habitats have been created or modified by humans or beavers. These include: excavated, impounded, diked, partly drained, farmed, and artificial (i.e., nonvegetated substrates emplaced by humans). Special Modifiers may be used singly or in combination wherever they apply.

\section{Regionalization}

In the USFWS classification, a given taxon has no particular regional alliance; its representatives may be found in one or many parts of the United States. Yet, for the purpose of planning and for organization, retrieval, and interpretation of inventory data, it is important to be able to place habitats within a regional context. The USFWS classification adopted Bailey's (1976, 1978) classification and map of ecoregions of the United States to fill the need for regionalization inland. Bailey's hierarchical classification addresses subcontinental and regional differences in climate as well as major vegetation types. Cowardin et al. (1979: Fig. 7) (Fig. 2), developed 10 additional provinces for the Marine and Estuarine areas of the United States.

\section{Key aspects of the approach and rationale}

\section{Classification by individual components}

In most North American wetland classifications developed prior to Cowardin et al. (1979), (e.g., Martin et al. 1953; Stewart \& Kantrud 1971; Golet \& Larson 1974; Jeglum et al. 1974; Zoltai et al. 1975) traditional terms, such as marsh, swamp, bog, fen, and wet meadow played a central role. The first draft of the current USFWS classification (Cowardin \& Carter 1975) also used such terms. However, after two national reviews and many months of haggling over definitions, the authors of the USFWS system agreed that the meaning of terms such as swamp and bog varies so widely across the United States that it would be a mistake to base a national classification on them. Rather than try to force users nationwide to adopt new, standardized definitions for these familiar terms - and risk failure the authors decided to abandon this traditional terminology and, instead, to create a classification of wetland components (i.e., vegetative life form, substrate composition and texture, water regime, water chemistry, and soil). Our belief was that the latter approach to classification would be more direct, more accurate, and less likely to result in national inventory statistics that were meaningless because of regional variations in the interpretation of classification taxa. Moreover, it soon became clear that, once a wetland's separate components were classified, it was relatively easy to 


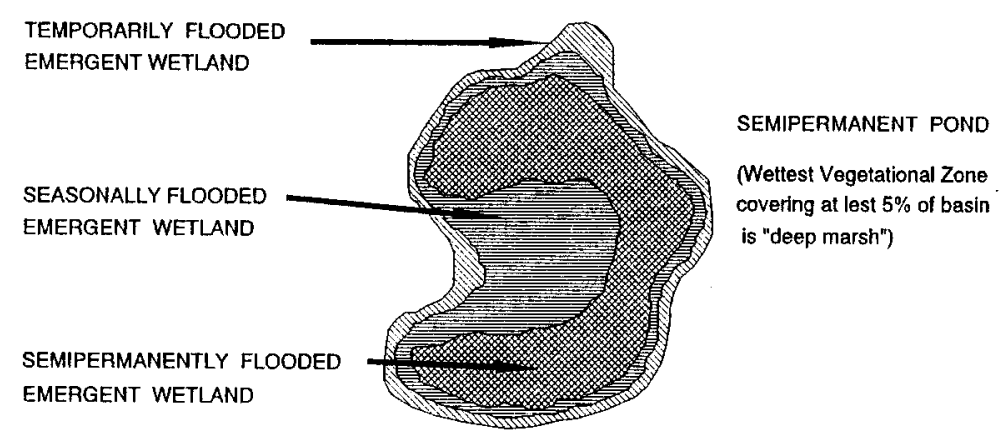

Fig. 2. Comparison between the zone classification of Cowardin et al. (1979) and the basin classification of Stewart and Kantrud (1971). In actual mapping by the National Wetlands Inventory the narrow marginal zones may be too small delineate and classify individually.

determine which of the more traditional terms, such as swamp, bog, or marsh, would be appropriate within a given region of the country.

The decision to change to a "classification by components' was resisted strongly by some, including some of the authors themselves, but in the end, we were satisfied that what was lost in colorful mental images was more than regained in accuracy of classification. We also want to stress that we view the continued use of more traditional regional classifications as wholly appropriate if they better serve a user's particular need. The advantage of using the USFWS classification is national consistency.

\section{Inclusion of nonvegetated habitats}

Based on recommendations presented at the July 1975 classification workshop (Sather 1976), the authors of the USFWS classification made another major departure from traditional practice: the wetland definition and classification were extended to a wide variety of nonvegetated habitats such as beaches and rocky shores. The thinking was that it is hydrology, not the presence of vegetation, that determines the existence of wetland. It seemed to make little sense to ignore nonvegetated habitats such as mud flats, while calling contiguous vegetated habitats, with virtually the same water regime, wetland. Actually, the trend to include nonvegetated areas in the concept of wetland was apparent even in Martin et al. (1953). That classification, designed primarily for waterfowl habitat, included inland and coastal saline flats along with 14 vegetated wetland types and 4 open-water types.

\section{Classification of habitat zones}

Under the USFWS classification, homogeneous areas or zones within wetlands are delineated and classified individually, in the same manner as a forest stand classification. Thus, the number of classes within a single wetland basin may vary widely, depending on the diversity of habitats within the basin and the scale of the remote sensing imagery and final maps on which the wetlands are delineated. This approach contrasts sharply with basin classification, where a single taxon is applied to an entire basin, regardless of the habitat diversity within the basin (e.g., Stewart \& Kantrud 1971). Although these two approaches are quite different, it is possible, in some cases, to generate a basin class from the separate polygons classified on an NWI map. Figure 2, for example, compares two classifications of a hypothetical Palustrine wetland: a zonal classification by Cowardin et al. (1979), as it might appear on an NWI map, and a basin classification by Stewart and Kantrud (1971). Under the Stewart and Kantrud approach, the wetland basin class is determined by the zone with the most permanent water regime provided that the zone occupies at least 5 percent of the basin.

In this example, the zone on the NWI map is 'semipermanently flooded emergent wetland' (equivalent to 'deep marsh' zone recognized by Stewart and Kantrud). Based on this information, the wetland basin would be classified as a 'semipermanent pond' under the Stewart and Kantrud system.

One method of classification is not inherently superior to another. They merely serve different purposes. The authors of the USFWS classification chose to construct a classification of habitat zones for several 
reasons: (1) A national classification must be applicable to wetlands that vary greatly in size. For Marine, Estuarine, and Riverine Systems, a basin classification has little meaning, although entire estuaries or river systems can be, and have been, classified for certain purposes (e.g., Odum et al. 1974). Similarly, large Palustrine-Riverine-Lacustrine complexes simply do not lend themselves to basin classification; (2) If the inventory map furnishes sufficient detail on the characteristics of individual wetland zones or polygons, it is sometimes possible to derive basin classifications, as noted in the paragraph above. Thus, NWI maps may serve the needs of various users with different purposes. However, combining mapping units to produce new taxa may be difficult, especially if an attempt is made to automate the process; (3) The inventory was to be accomplished primarily through interpretation of high-altitude aircraft imagery, and, generally, it is far easier to identify and delineate habitat zones than entire basins, particularly in areas of low topographic relief.

\section{Inventory demands}

Although the primary goal of the authors of the USFWS wetland classification was to produce an ecologically meaningful system for describing wetland habitats, some modifications were required to accommodate use of high-altitude aerial photographs. Certain important wetland characteristics or attributes that might be readily recognized in the field could not be consistently distinguished on high-altitude imagery; as a result, such characteristics were either relegated to the lowest levels of the classification hierarchy (e.g., Dominance Type) or to the Modifiers (e.g., water regime, water chemistry), or they were dropped from the classification altogether. The practical needs of the inventory thus had an influence on the final form of the classification. Inventory-related constraints are discussed in more detail below, under 'Limitations of Remote Sensing'.

\section{Relation to regulatory programs}

When the authors of the classification first invited comment from various federal and state agencies on how the classification and inventory should be structured, we were frequently asked to align both the definition of wetland and the structure of the classification with state and federal laws and regulations. We chose not to do this. Laws and regulations vary significantly among agencies. They are drafted for various purposes, and they may or may not have an ecological basis. We were convinced that, without separation from the problems of wetland regulation, the classification would not have been completed, and the inventory would have been hopelessly mired. Each NWI map has the following statement printed on it:

There is no attempt in either the design or products of this inventory to define the limits of proprietary jurisdiction of any Federal, State, or local government or to establish the geographical scope of the regulatory programs of government agencies.

We believe that with an understanding of the structure and purpose of the classification, as well as the strengths and weaknesses of the inventory products, governmental agencies can use the products as an aid to regulatory decisions.

\section{Principal problem areas}

Among the most significant problems encountered during development and application of the USFWS wetland classification were (1) the definition of wetland, (2) the definition of classification taxa; (3) the lack of basic ecological data to support the classification; and (4) the limitations of remote sensing. Each of these problems is discussed below.

\section{Definition of wetland}

The definition of wetland is the most basic step in wetland classification, inventory, and management. Unfortunately, attempts to define wetland and to distinguish it from upland (nonwetland) are beset by a number of conceptual, as well as practical, problems. First, the moisture gradient in nature is continuous, and obvious breaks along that continuum are seldom observed, except at abrupt changes in topographic slope. Second, the diversity of hydrologic conditions over a geographic area as large as the United States is so great that it is practically impossible to write a concise definition to cover all situations. Third, while it is difficult to write a sound conceptual definition of wetland, it is even more difficult to develop reasonable, practicable rules for application of this definition in the field. Fourth, although the definition of wetland is a scientific matter, it also may be highly controversial because of land use or regulatory implications.

Hydrology is universally regarded as the most basic feature of wetlands (Gosselink \& Turner 1978; Carter et al. 1979; Mitsch \& Gosselink 1993), but it is also the 
most difficult parameter to describe accurately. Due to the great variations in physiography and climate across the United States, the hydrologic regimes of wetlands vary widely. Even at the same site, water levels and soil moisture frequently vary markedly among years and among seasons within the same year. 'Wetland hydrology' is easy to recognize in the interior of those wetlands where surface water is present all year, but not so easy near the wetland-upland edge, where boundaries must be drawn for purposes of inventory and land use regulation. To even approximate the longterm, prevailing water regime at a given site, groundwater levels or soil moisture would have to be monitored continuously over many years. Such long-term data are not now available - nor are they ever likely to be - except at isolated research sites. For these reasons, it is virtually impossible to write a hydrologic definition for wetland that is comprehensive, quantitative, and yet practical.

The USFWS wetland definition (Cowardin et al. 1979:3) states that wetland can be identified by any one of three features: a predominance of hydrophytes; a predominance of hydric soils; or, in areas where true soils and rooted plants do not exist, a substrate that is saturated with water or covered by shallow water at some time during the growing season of each year. When the authors wrote this definition, they assumed that most wetlands would be identified by their vegetation or their soils, the most obvious indicators of wetland hydrology. We labored long and hard over the wording of the third, or hydrologic, part of the wetland definition (see section above on 'Definition of Wetland and Deepwater Habitat' for exact wording). None of the authors was entirely pleased with the results, but after many months of discussions and review by wetland scientists and managers, we agreed that further modification was not warranted. The authors were pressured by some to quantify the hydrologic aspect of the wetland definition, and to state the minimum number of days of surface inundation or soil saturation required for an area to qualify as wetland, but we declined to do so. We cited as reasons the wide range of hydrologic conditions in the Nation's wetlands and the lack of long-term hydrologic data.

The authors of the USFWS wetland classification maintained that it is neither reasonable nor practicable to establish a quantitative hydrologic criterion for field identification of wetlands. We still believe that, in the great majority of cases, wetlands should be identified by vegetation and soils. We argue that hydrology should be used only where soil and vegetation crite- ria cannot reasonably be applied, such as in highly disturbed wetlands, and that any hydrologic criteria devised for those special circumstances must be consistent with the hydrologic criteria established for identification of hydric soils (Soil Conservation Service 1991).

Definitions of 'hydrophyte' and 'hydric soil' typically are circular, hydrophytes often being defined as plants that grow in wet soils and hydric soils being defined as soils that support wetland plants. To avoid this problem, the authors asked the USFWS to create a list of those plants that occur in U.S. wetlands (Reed 1988); the list then serves to define 'hydrophyte'. Similarly, they coined the term 'hydric soil' and asked the US Soil Conservation Service to define the term and to identify those specific soils nationwide that met the definition (Soil Conservation Service 1991). Development of these lists has been a prodigious task, but surprisingly successful. In each case, additions to the list required the unanimous agreement of National (and regional, in the case of plants) review teams, composed of wetland scientists from the major federal agencies concerned with wetlands (USFWS, US Soil Conservation Service, US Environmental Protection Agency, and US Army Corps of Engineers); University scientists also served on the National Technical Committee for Hydric Soils. The lists have been widely used by state and federal agency personnel, as well as academicians and private environmental consultants.

When Cowardin et al. (1979) wrote the definition of wetland, we also assumed that, in most vegetated wetlands, there would be a strong correlation between vegetation that was predominantly hydrophytic and soils that were predominantly hydric. The USFWS commissioned scientists at North Carolina State University (Wentworth and Johnson 1986) to develop numerical methods for identifying a 'predominance of hydrophytes', using the wetland plant list and indicator categories (Table 1). In 1985, the USFWS then launched a nationwide research effort to test the extent of agreement between the hydric status of soils and the presence of hydrophytic vegetation. These studies found that the agreement between hydric soils and wetland plants was close, with few exceptions (Scott et al. 1989; Segelquist et al. 1990). Despite this apparent success in making the conceptual definition of wetland operational, significant problems remain. One controversy centers on which of the categories of plants that occur in US wetlands (Reed 1988) are truly hydrophytes or 'wetland plants'. Tiner (1991), for example, has argued that not only Facultative 
plants, but Facultative Upland plants as well, are true hydrophytes under some circumstances. Others have suggested that only Obligate Wetland and Facultative Wetland plants should qualify as hydrophytes.

The USFWS wetland definition was proposed as an ecological, not a regulatory, definition, as already stated. Although some technical problems still remain, particularly in development of field methods for wetland identification, we believe that the scientific basis for that definition is even stronger today than when it was published in 1979. In our view, the definition of wetland is a scientific issue; the scope and intensity of wetland protection are policy issues. Although policy is of critical importance, we do not believe that it should overrule science in scientific matters.

\section{Definition of classification taxa}

By its very nature, habitat classification is problematic because it is an attempt to place artificial boundaries on natural continua. Wetland classification is a prime example. One of our greatest sources of frustration was our inability to clearly define what we perceived as real boundaries between distinct categories of wetlands or wetland characteristics. In some cases, the problem was caused by a lack of basic ecological data; in other cases, we were constrained by the limitations of remote sensing. The definitions of Systems and Water Regime Modifiers gave us the most difficulty.

The authors of the classification and many reviewers would have preferred - at least initially - to see river floodplains placed in the Riverine System, but they soon discovered that it simply was not possible to consistently locate the landward edge of floodplains, either in the field or on high-altitude aerial photographs. This was especially obvious in densely forested terrain where topographic relief was negligible, such as much of the southeastern United States and the Great Lake States. In some areas, rivers course through large emergent wetlands with interspersed lakes, making distinction between river floodplain and lakeshore wetlands almost impossible. Consequently, the authors altered the traditional concept of riverine, limiting it to the river channel (including nonvegetated classes, Aquatic Beds, and Nonpersistent Emergent Wetlands). Persistent wetland vegetation, such as Forested, ScrubShrub, and Emergent Wetlands of the adjacent floodplain, was classified as Palustrine. To be consistent in concept and in practice, they drew the boundary of the Lacustrine System at the edge of upland or at the edge of persistent (i.e., Palustrine) wetland vegetation.
The separation of Systems on the basis of persistence of vegetation, while it has some merit, becomes awkward where islands of persistent vegetation occur within river channels or lake basins. NWI staff apprised the authors of the problems created by basing one of the uppermost distinctions in the classification hierarchy (i.e., distinction between Systems) on a feature that cannot always be determined through remote sensing. Using salinity $(0.5 \mathrm{ppt})$ to distinguish coastal from inland Systems has created similar problems. The classification forces the use of data sources other than remote sensing imagery.

Perhaps the most imprecise facet of the USFWS classification is the definition of Water Regime Modifiers. We readily admit that these modifiers are only crude approximations of some of the more common hydrologic situations observed in nature. Some Water Regime Modifiers, such as irregularly flooded, seasonally flooded, and saturated, are too broad to be useful in many cases. Complex water regimes, such as those associated with seiches in lakes, cannot be adequately described by the present water regime modifiers. Additions and modifications are needed. The authors were asked by some reviewers to quantify, in days or weeks, the duration of flooding or soil saturation for each Modifier, but they argued that was inappropriate in light of the lack of data on which to base such figures. Moreover, it would be impractical to have to verify that any such quantitative criteria were met prior to classification of specific sites.

The authors limited consideration of water regime in nontidal areas to the growing season, arguing that the presence of water at that time of year was most significant to vegetation. However, water levels during the dormant season may be of critical importance for certain wetland functions such as floodwater retention and wintering waterfowl habitat. In some regions, the growing season runs virtually year-round. We are confident that the current Water Regime Modifiers can be improved, but the extent of refinement ultimately will be determined by practicality and the availability of basic ecological data.

\section{Lack of basic ecological data}

One common approach to classification is to assemble the elements to be classified, describe their attributes, and then group them, often in a hierarchical structure. This approach may employ complex statistical methodology (Anderberg 1973). Developing the classification for the NWI was, in some respects, the 
reverse of this process. First the taxonomy was created, based on published descriptions, experience, and tradition; the result was like a large ordered set of pigeonholes. Next, descriptions of the taxa were written in an attempt to assure that an element would be placed in the right pigeonhole. Finally, the user gathered the elements, applied the definitions, and attempted to place each element in a pigeonhole. The last step was equivalent to the NWI mapmaker adding the identifier to a polygon on a map.

This reverse classification procedure had a number of shortcomings, but it was the only choice, because of the lack of supporting data. Cowardin recalls that when he was just starting work on the classification he made a trip to Alaska and met with Dr Bonita Wieland (University of Alaska, Fairbanks). He was asking questions about the vegetation, soils, and hydrology of Alaskan wetlands. Dr Wieland replied, 'You realize that nobody has ever been in many of the wetlands in Alaska'. Even in the lower 48 states there are many wetlands where the basic data necessary for accurate classification are unavailable. The authors also frequently discussed whether a taxon that was being included in the classification actually existed. They had such a discussion about Unconsolidated Shores with an Organic substrate. In 1985 Golet observed this type of wetland in western Alaska, and a photograph of it (Plate 47) was included in the first reprinting of the classification.

Despite the lack of data, the authors found that the classification system often worked well in areas where they had little experience. We are not suggesting that classification be delayed until all wetlands have been described in detail, but we do want to stress that the process of classification does not produce any data. Nevertheless, misclassification does produce errors in wetland inventory data. It is important that basic ecological studies of wetlands be accelerated. As new data become available, refinements in the USFWS classification will be possible.

\section{Limitations of remote sensing}

Wetland management decisions are often based on data presented on maps or on data bases derived from maps. Maps are one product of the NWI. Map-based data have the advantage of being readily available. Some decisions cannot be deferred until intensive ground studies are conducted. The trend toward the use of mapbased data will accelerate in the future because of the increasing availability of geographic information systems and computer equipment that allow rapid access to spatial data and complex analyses, which were not practical in the past. Map data, however, have limitations and present problems for wetland classification.

Mapping conventions cannot include all of the detail available in the USFWS classification. Classifications used for mapping are scale-specific (Kuchler 1988). There is a limit to the size of a mapping unit that can practically be placed on a map and to the size of a water body or stand of vegetation that can be interpreted from a photograph. The standard NWI maps have a scale of 1:24000 and most are prepared from high-altitude (1:58000 or smaller scale) color-infrared photographs. The inventory staff prepared a standardized set of scale-specific mapping conventions based on the classification. Even at this scale, which is large in comparison to data derived from satellites such as LANDSAT (Jacobson et al. 1987), some entire wetland basins and many wetland areas around the margins of basins are not detectable or mappable.

There are also limits to what can be interpreted from a single aerial photograph or remote sensing image. Wetland dynamics present a difficult problem for remote sensing because surface water may or may not be present on a wetland, and the dominant vegetation can vary in both species composition and life form within and among years. Thus a high degree of ecological expertise and familiarity with local areas are required of the photointerpreter. Interpretation of water regimes and sometimes classes in the USFWS classification often requires more than one set of photographs, or supplemental data.

The ordering of the taxa in the classification hierarchy is ecologically based, instead of being geared primarily to the use of remote sensing as are the classes in the national land use classification of Anderson $e t$ al. (1976). The need to consistently identify Systems has forced the NWI to use supplementary sources of data such as maps of tidal influence and soils, as well as ground study of sample sites. Some of the components of the classification such as water chemistry, though critically important in wetland ecology, cannot be determined from photographs and have been omitted from NWI maps. The Class level in the hierarchy, based on life form of vegetation and substrate form and texture, should be the most easily photointerpreted taxon. Even here, however, there are difficult interpretation problems, such as distinguishing Emergent Wetland from Scrub-Shrub Wetland in Alaskan tundra (Cowardin et al. 1979: Plate 75). 


\section{Future directions}

\section{Anticipated changes in the classification}

Since the publication of the classification in 1979, NWI staff have been compiling a list of problem areas for which revisions of the classification are needed. In addition, new users, new data, and new methodologies for describing wetlands have become available. There appears to be a need for revision. However, the inventory is nearing completion, and products are being converted to expensive digital form at an increasing rate, thus imposing severe limits on the nature and extent of revision that is practical. We suspect that any revisions will be in the form of clarification of definitions of the taxa and possibly additions to the hierarchical structure. A major redesign of the classification would invalidate comparisons with past mapping and databases.

\section{Explosion of remote sensing and GIS technology}

There is already an increasing need for rapid development of up-to-date wetland maps. New remote sensing products, especially those coming from satellites, will be developed. Techniques involving multispectral scanners have been used to determine water quality (Dekker et al. 1991) and water depth (Lyon et al. 1992). These advances will increase the demand for classifications that are applicable to computer processing. It is doubtful that the USFWS classification can be completely compatible with automated procedures, but it can provide the basis for mapping conventions developed for special inventories. These types of inventories should be viewed as complementary to the NWI, rather than competitive with it. The purposes and limitations of both kinds of classifications and data sets must be understood (Koeln et al. 1988).

\section{Wetland functional assessment}

As realization of the importance of wetlands to society has grown, regulations that protect wetlands and restrict human activities in wetlands have increased as well. The USFWS wetland classification and the inventory based on it were not intended for regulatory purposes. Agencies such as the US Army Corps of Engineers and the US Environmental Protection Agency must make regulatory decisions. As a result, there has been increased interest in wetland values to society (Mitsch \& Gosselink 1993, Chapter 15). One way of evaluating wetlands is to determine their functions and to determine how human activities affect these func- tions or vice versa (Sather \& Smith 1984). Wetland function has become an increasingly important component of recently proposed classifications (Clairain 1985). Classification and inventory of wetland functions are difficult to achieve, however, considering the current state of our knowledge. Functions of certain wetland types are frequently unknown. Therefore, detailed studies of individual wetlands may be necessary before functional classification can proceed. The problem is similar to the problem of wetland definition based on hydrology, which frequently is not measurable and must be inferred from other attributes. In some cases, function can be broadly inferred from the taxa in the USFWS classification, but in many cases such inference will have to wait for additional basic wetland research.

\section{Global wetland classification}

\section{Potential benefits}

A standard, global wetland classification would do much to advance the causes of wetland science and management worldwide. One benefit would simply be a standard terminology for communication about wetlands. This, in itself, would permit greater understanding of wetland diversity and functions. Standard terminology also would allow more effective comparisons and integration of research results from different parts of the world. Global classification would facilitate the development of coordinated research efforts for particular, widely distributed, wetland ecosystems, resulting in more rapid advances in our knowledge and less duplication of effort. Finally, global classification would provide the basis for a global wetland inventory, periodic monitoring of wetland extent and condition, improved management of migratory wildlife habitats on an international basis, and more accurate assessments of the global significance of wetlands to humankind.

\section{Some important considerations}

We view the following as key considerations in the development of a global wetland classification:

1. No single system can accurately portray the diversity of wetland conditions worldwide. Some important ecological information inevitably will be lost through classification. Despite this fact, a sincere effort should be made to incorporate as much of this diversity as possible into the basic classifica- 
tion structure, so that the system truly represents the global wetland resource. Regional, national or continental modifiers might be provided at the lowest levels of the classification hierarchy to assure that unique, but geographically restricted, wetland types are covered.

2. Classification taxa must be clearly defined and readily distinguishable, both in the field and on a variety of remote sensing products. A 'classification by components', such as the USFWS system, would appear to be the most objective approach. Geographically specific terms such as bayou, reedswamp, arroyo, fen, and billabong should be avoided.

3. Insofar as possible, the classification taxa should be functionally relevant, but due to the dearth of information on the relationship between wetland attributes and functions, it seems unwise to pursue a functional classification of wetlands at this time.

4. The classification should be based in ecology, not regulatory concerns, and value-related biases should be avoided. Currently at least, the perceived values of wetlands to society vary widely around the world as a result of wide-ranging socioeconomic conditions, political ideologies, and cultural traditions. International cooperation in efforts such as wetland classification and inventory may eventually lead to more uniform, global policies for wetland management, but that goal cannot logically be addressed through the classification and inventory process.

5. Careful consideration must be given to the development of a wetland definition that will encompass the diversity of wetland conditions world wide, and, at the same time, be operationally effective at any field location.

6. Special efforts should be made to guarantee compatibility among any global wetland classification and existing national or international systems. The correspondence between global classification taxa and more colloquial terms (e.g., bog, marsh, reedswamp) should be addressed as well, possibly as an appendix or supplement to the classification.

\section{Conclusions}

We have reviewed the history of development of the USFWS wetland classification and sketched its structure. Despite undisputed problems, we believe that the classification has met its stated objectives. In the Unit- ed States we found that there is extreme variation in wetlands, and the variation will be far greater on an international scale. The authors of the U.S. classification also found that each had personal biases based on experience. Ideas that worked well in familiar territory were found to be unworkable elsewhere. An international effort will require a diversity of geographical and technical expertise.

Our experience in the United States suggests that development of a classification should follow five steps in chronological order:

1. The purpose for, and ultimate users of, the classification must be clearly identified.

2. Data sources and methodology for data gathering must be reviewed. This step will identify constraints that will affect the structure of the classification.

3. A classification structure should be drafted. Our experience suggests that there are advantages to a hierarchical structure and that, as much as possible, the structure should follow established, and accepted, concepts. Drafting the structure is, perhaps, the easiest and least time-consuming step.

4. Detailed definitions for wetland and for each taxon of the classification must be written. This essential step is the most difficult and controversial.

5 . The system must be tested on a wide array of different wetland classes over a broad geographic area.

Hopefully, discussions generated at this symposium will lead to an international system of classification and inventory that can be used to protect wetland ecosystems. The task will be immense, but it is time to begin.

\section{Acknowledgments}

We acknowledge the major contribution of our coauthors of the classification, V. Carter and E. T. LaRoe. Without the efforts of J. H. Montanari, W. O. Wilen, and J. H. Sather, as well as the entire NWI staff, the classification would never have been completed. We hope that this historical review is accurate in the minds of the many individuals involved in the development and testing of the classification. V. Carter, J. H. Montanari, J. H. Sather, L. L. Strong, J. E. Austin, J. T. Lokemoen, and D. H. Johnson kindly reviewed earlier drafts of this paper. 


\section{References}

Anderberg, M. R. Cluster analysis for applications. Academic Press, New York. 359 pp.

Anderson, J. R., Hardy, E. E., Roach, J. T. \& Witmer, R. E. 1976. A land use and land cover classification system for use with remote sensor data. US Geological Survey Professional Paper 964. 28 pp.

Bailey, R. G. 1976. Ecoregions of the United States. US Forest Service, Ogden, UT. (map only; scale 1:7500 000).

Bailey, R. G. 1978. Ecoregions of the United States. US Forest Service, Intermountain Region, Ogden, UT. 77 pp.

Carter, V., Bedinger, M. S., Novitzki, R. P. \& Wilen, W. O. 1979. Water resources and wetlands. Pages 344-376 in P. E. Greeson, J. R. Clark and J. E. Clark, eds. Wetland functions and values: the state of our understanding. American Water Resources Association, Minneapolis, $\mathrm{MN}$.

Clairain, E. J., Jr. 1985. National wetland functions and values study plan. Transactions North American Wildlife and Natural Resources Conference 30: 485-494.

Cowardin, L. M. \& Carter, V. 1975. Tentative classification for wetlands of the United States. US Fish and Wildlife Service Office of Biological Services Washington, DC Rep. 43 pp. (mimeo)

Cowardin, L. M., Carter, V., Golet, F. C. \& LaRoe, E. T. 1976. Interim Classification of wetlands and aquatic habitats of the United States. Addendum to J. H. Sather, ed. Proceedings of the National Wetland Classification and Inventory Workshop. 1975. US Fish and Wildlife Service. FWS/OBS 76/09.

Cowardin, L. M., Carter, V., Golet, F. C. \& LaRoe, E. T. 1979. Classification of wetlands and deepwater habitats of the United States. US Fish and Wildlife Service FWS/OBS 79/31. 103 pp.

Dekker, A. G., Malthus, T. J. \& Seyhan, E. 1991. Quantitative modeling of inland water quality for high-resolution MSS systems. IEEE Transactions Geoscience and Remote Sensing 29: 89-95.

Golet, F. C. \& Larson, J. S. 1974. Classification of freshwater wetlands in the glaciated Northeast. US Fish and Wildlife Service Resource Publication. $116.56 \mathrm{pp}$.

Gosselink, J. G. \& Turner, R. E. 1978. The role of hydrology in fresh-water wetland ecosystems. Pages 63-78 in R. E. Good, D. F. Whigham, and R. L. Simpson, eds. Freshwater wetlands: ecological processes and management potential. Academic Press, New York.

Jacobson, J. E., Ritter, R. A. \& Koeln, G. T. 1987. Accuracy of Thematic Mapper derived wetlands as based on National Wetland Inventory data. Pages 109-118 in American Society Photogrametry and Remote Sensing Technical Papers, 1987 ASPRS-ACSM Fall Convention, Reno, NV.

Jeglum, J. K., Boissoneau, A. N. \& Haavisto, V. F. 1974. Toward a wetland classification for Ontario. Canadian Forest Service Information Report O-X-215. 54 pp.

Koeln, G. T., Jacobson, J. E., Wesley, D. E. \& Rempel, R. S. 1988 Wetland inventories derived from LANDSAT data for waterfowl management planning. Transactions North American Wildlife and Natural Resources Conference 53: 303-310.

Kuchler, A. W. 1988. Aspects of maps. Handbook of vegetation science, Vol. 10: 97-1040.

Lyon, J. G., Lunetta, R. S. \& Williams, D. C. 1992. Airborne multispectral scanner data for evaluating bottom sediment types and water depths of the St. Marys River, MI. Photogramtric Engineering and Remote Sensing. 58: 951-956.

Martin, A. C., Hotchkiss, N., Uhler, F. M. \& Bourn, W. S. 1953. Classification of wetlands of the United States. US Fish and Wildlife Service Special Scientific Report Wildlife. 20.14 pp.
Millar, J. B. 1976. Wetland classification in westem Canada: a guide to marshes and shallow open water wetlands in the grasslands and parklands of the Prairie Provinces. Canadian Wildlife Service Report Series 37.38 pp.

Mitsch, W. J. \& Gosselink, J. G. 1993. Wetlands, 2nd ed. Van Nostrand Reinhold, New York, 539 pp.

Odum, H. T., Copeland, B. J. \& McMahan, E. A. (eds) 1974. Coastal ecological systems of the United States. The Conservation Foundation, Washington, DC. 4 Vol.

Reed, P. B. 1988. National list of plant species that occur in wetlands: national summary. US Fish and Wildlife Service Biological Report. 88(24). 244 pp.

Sather, J. H. 1976. Proceedings of the National Wetland Classification and Inventory Workshop. US Fish and Wildlife Service, Washington, DC $248 \mathrm{pp}$.

Sather, J. H. \& Smith, R. D. 1984. An overview of major wetland functions and values. US Fish and Wildlife Service Office of Biological Services. FWS/OBS 84/18. 68 pp.

Scott, M. L., Slauson, W. L., Segelquist, C. A. \& Auble, G. T. 1989. Correspondence between vegetation and soils in wetlands and nearby uplands. Wetlands 9: 41-60.

Sculthorpe, C. D. 1967. The biology of aquatic vascular plants. Edward Arnold Ltd., London. $610 \mathrm{pp}$.

Segelquist, C. A., Slauson, W. L., Scott, M. L. \& Auble, G. T. 1990 Synthesis of soil-plant correspondence data from twelve wetland studies throughout the United States. US Fish and Wildlife Service Biological Report. 90(19). 24 pp.

Shaw, S. P., Fredine, C. G. 1956. Wetlands of the United States. US Fish and Wildlife Service Circular $39.67 \mathrm{pp}$.

Soil Conservation Service. 1982. Hydric soils of the United States. US Department of Agriculture National Bulletin. 430-2-7. (January 4,1982 ).

Soil Conservation Service. 1985. Hydric soils of the United States. US Department of Agriculture and National Technical Committee for Hydric Soils, Washington, DC.

Soil Conservation Service. 1987. Hydric soils of the United States. US Department of Agriculture, in cooperation with the National Technical Committee for Hydric Soils, Washington, DC.

Soil Conservation Service. 1991. Hydric soils of the United States. US Department of Agriculture Miscellaneous. Publication. 1491, in cooperation with the National Technical Committee for Hydric Soils. Washington, DC

Soil Survey Staff. 1975. Soil taxonomy: a basic system of soil classification for making and interpreting soil surveys. US Soil Conservation Service Agricultural Handbook 436.754 pp.

Stewart, R. E. \& Kantrud, H. A. 1971. Classification of natural ponds and lakes in the glaciated prairie region. US Fish and Wildlife Service Resource Publication. 92. 57 pp.

Tiner, R. W. 1991. The concept of a hydrophyte for wetland identification. BioSience 41: 236-247.

Welch, P. S. 1952. Limnology, 2nd ed. McGraw-Hill, New York. $538 \mathrm{pp}$.

Wentworth, T. R. \& Johnson, G. P. 1986. Use of vegetation in the designation of wetlands. US Fish and Wildlife Service, National. Wetland Inventory, Washington, DC. $107 \mathrm{pp}$.

Wilen, B. \& Bates, M. K. 1995. The United States national wetlands inventory. Vegetation (in press)

Zhadin, V. I. \& Gerd, S. V. 1963. Fauna and flora of the rivers, lakes and reservoirs of the USSR. Oldbourne Press, London. $626 \mathrm{pp}$.

Zoltai, S. C., Pollett, F. C., Jeglum, J. K. \& Adams, G. D. 1975. Developing a wetland classification for Canada. Proceedings North American Forest Soils Conference 4: 497-511. 